\title{
Evaluation of investing in real estate in EU and non-EU countries based on MCDM
}

\author{
Seyit Ali Erdogan ${ }^{1}$, Andrej Naumčik ${ }^{2}$ \\ Department of Construction Management and Real Estate, Faculty of Civil Engineering, \\ Vilnius Gediminas Technical University, Vilnius, Lithuania \\ E-mail: '1ali_erdogan1907@hotmail.com (correspondingauthor)
}

\begin{abstract}
Investment in real estate is a zoning issue as the real estate market is closely related to economic development and trends in real estate market are considered to be indicators of trends in the whole economy of the country. The goal of this paper is to analyse the main aspects and considerations when investing in real estate, evaluate investment in real estate situation in different EU and non-EU countries and introduce MCDM methods that could be used for selecting a state for investment in real estate.

It is identified that when investing in real estate various political, social, economic, environmental and other factors have to be taken into consideration.

Analysed examples of EU (Lithuania, Romania, UK) and non-EU (Turkey, China, Russia) countries show different risks and opportunities for investments in real estate.

MCDM methods are applicable to evaluate which countries are most attractive for investment in real estate. Described TOPSIS and ARAS methods could be used for assessing states as alternatives when selecting where to invest.
\end{abstract}

Keywords: investment in real estate, MCDM, investing in EU countries, investing in non-EU countries, investment factors.

\section{Introduction}

Real estate market closely related to economies of countries', prominent real estate projects can influence economic growth in an area. The real estate market is of great importance to both economic and social development of a country (Canas, Ferreira, \& Meidute-Kavaliauskiene, 2015).

Trends in real estate sector and real estate development projects in the country are acknowledged as a significant indicator of trends in the whole economy (Golob, Bastic, \& Psunder, 2012) and also shape the picture of the needs of the society (Squires \& Heurkens, 2016).

Investment in real estate is defined as economic behaviour when money and other resources are put into real estate development and management to achieve maximum profits (Wu \& Kou, 2016). Real estate investment could also mean investing in a land area with the target to increase its value through development projects (Olsson, Sorensen, \& Leikvan, 2015).

Investing in real estate could be very profitable, but the investor has to consider various risks connected to political, economic, social, environmental and other factors.

The goal of this paper is to analyse the main aspects and considerations when investing in real estate, evaluate investment in real estate situation in different EU and non-EU countries and introduce MCDM methods that are useful to selecting a state for investment in real estate.

\section{Main aspects of investing in real estate}

When investing in real estate, an investor has to consider the aspects of the local market. Economic, social, cultural, political and other market features vary a lot depending on the country chosen for investment.

Risks connected to investments in real estate are recognised as the risk of losing invested capital or the expected return not covering the losses (ML \& Wp, 2012).

Real estate market is very complex and usually very sensitive to shifts in economic and social factors in the country such as GDP, unemployment rate, demographics, salaries etc. (Anghel \& Hristea, 2015). 
One of the most important determinants of real estate investment is the price that is highly influenced by demand and supply. Also, real estate prices are closely connected to GDP, unemployment rate, household income, interest rate, industrial production and consumption of households etc. For example, interest rates affect capital flows as well as supply and demand for capital (Tem \& Komsuoglu Yilmaz, 2018). When interest rates are growing, potential buyers are getting discouraged as the cost of taking bank credit is rising. As a result, the demand for properties is decreasing. On the opposite, when interest rates are declining, the need for housing is growing (Panagiotidis \& Printzis, 2015).

The absolute majority of residential and commercial property purchases involve borrowing in countries with advanced economies (Crowe, Dell'Ariccia, Igan, \& Rabanal, 2013).

Taxation of real estate in the country influences property. Governments of many countries in Eurozone encourage investments in residential real estate through tax deductions (Panagiotidis \& Printzis, 2015). Real estate transfer tax differs significantly among countries and is a vital source of government revenue (Fritzsche \& Vandrei, 2019). It is noted that. Prices of property generally are very different in capitals and smaller towns of the country (Grum $\&$ Govekar, 2016). Kelly (2018) stressed that high rates of residential real estate hurt economic growth.

Political factors have to be considered as well when choosing a country for investment in real estate. Political stability and good relations with other countries as well as the level of corruption in the country influence the attractiveness of investment opportunities for foreign investors.

Laws and regulations in the country that regulate real estate market are significant when investing as well. Sound legal structures and protection of property rights are of utmost importance for investments (Lieser \& Groh, 2010).

Global financial crises exposed the risks related to real estate booms. Researches indicate that the real estate market could become the reason of vulnerability or even crisis (Cetkovic et al., 2018). It is stressed that crises related to weaknesses in residential property markets were quite common throughout history (Bengtsson, Grothe, \& Lepers, 2018). The risks of financial and real estate crisis grow with globalization processes as markets become more integrated.

Finally, environmental factors are of consideration when investing in real estate. It is essential to evaluate risks that can arise from the environment of real estate project, for example, it could be rising sea level, like in Miami, localised risks of climate change (Bunten \& Khan, 2017) as well as the possibility of earthquakes, tsunamis, seismic activities etc. Besides, environmental factors such as air pollution, recreational areas, distance to markets, hospitals, schools, neighbourhood features etc. have to be evaluated (Zrobek, Trojanek, Zrobek-Sokolnik, \& Trojanek, 2015).

\section{Investment in real estate in $\mathrm{EU}$ and non $\mathrm{EU}$ countries}

Investing in real estate and risks connected with such operations can differ significantly depending on the country chosen for investment.

\section{Lithuania}

Lithuania is considered to be a relatively safe choice for investing in real estate. The country has been part of the EU since 2004 and is also a member of NATO, UN and other critical global organisations that contribute to the stability of the country.

Lithuania's growing economic development is based on the domestic demand which is induced by private consumption (Tupenaite, Kanapeckiene, \& Naimaviciene, 2017).

Main macroeconomic factors affecting residential real estate prices in Lithuania are inflation rate, GDP, interest rate and availability of loans from banks (Gaspareniene, Remeikiene, \& Skuka, 2016).

Favourable economic conditions, growing salaries, political stability, availability of bank credit and other factors make Lithuania appealing country for investing in real estate.

\section{Romania}

Romania is another EU country and an attractive destination for investments in real estate. It is noted that the country's real estate sector heavily depends on the credits from the banks while other Europe's countries explore and exploit non-banking sources as well. Both Lithuania and Romania are among the top countries in Europe by the percentage of house owners (Anghel \& Hristea, 2015).

Western and central regions of Romania are more developed and more competitive than other parts of the country. They are quickly assimilating with European culture and spirit, e.g. decentralisation, competition, tolerance. On the other hand, in other regions ethnic diversity of Romania is more obvious (Surd, Kassai, \& Giurgiu, 2011).

Romania is an appealing country for investing in real estate as its laws and regulations are favourable for international investors, it has massive touristic potential, stable and competitive fiscal policy, one of the lowest taxes on incomes, dividends and profits in EU, lower market prices than in many EU countries, possibility to get financial support from structural and national funds for infrastructure projects etc. (Anghel \& Hristea, 2015). 


\section{The UK}

Residential property market is a critical element of the UK's economic operations. The country has a considerably high owner-occupation rate (Tse, Rodgers, \& Niklewski, 2013).

The UK, while still being part of the EU, has tapped into a phase of national political instability connected to Brexit issues creating a lot of concerns for future profitability and security of investments in real estate. People of UK voted to leave EU in 2016 summer, and that started chaos in the political scene with the resignation of Prime Minister David Cameron (Schiereck, Kiesel, \& Kolaric, 2016).

On the other hand, it should be noted that real estate laws and regulations in England, Scotland and Wales have minimum intervention at EU level. So it is argued that Brexit will have a small influence on the way that UK's real estate operations are managed. However, there is little certainty about Brexit's economic effect on the real estate sector (Allen \& Overy, 2016).

Turkey

A lot of foreign investments are attracted by the real estate sector of Turkey. The country has unique geographical location being the connecting point of Europe and Asia which has been very advantageous in forming cultural and historical linkages with neighbouring countries and becoming energy bridge between global markets and source rich countries of the Caspian region and the Middle East (Gokmen, 2014).

Despite the unsuccessful attempt of the coupe in summer 2016, the state managed to establish itself as politically stable. It is important to note that Turkey has created Custom Union (CU) with EU and also is a member of such global organisations like World Trade Organization (WTO), UN, International Monetary Fund (IMF) and World Bank (WB) (Gokmen, 2014).

Investing in real estate in Turkey could be promising as it is one of the largest economies in Europe with a huge domestic demand for properties (Cagli, 2018). Besides, due to the current fall of national currency Turkish Lira, it could be the best time to invest in real estate and expect high profits in the future.

\section{China}

China is another non-EU country with great potential for foreign investors. Some authors (Anghel \& Hristea, 2015) believe that China has the potential to become a country of maximum interest for the real estate investors.

Like in other countries, the real estate sector is a significant part of the country's economy and financial system (Liu \& Xiong, 2018). The rapid development and expansion of China's real estate market have been an element of the country's dramatic economic growth (Wu, Gyourko, \& Deng, 2015). Urbanisation processes in China have been very rapid during the last few decades creating an increase in property prices in major cities (Chen, Wang, \& Liu, 2015). The government carefully monitors operations in the real estate sector. Policies regulating the real estate market are very decentralised; local governments are making decisions connected with land sales and developments of infrastructure. Local governments are given the power of granting deals and construction permission for developers and making restrictions for purchases (Ding, Huang, Jin, \& Lam, 2017).

Russia

Even though Russia is the biggest country in the world by area size, it is very centralised with all financial resources, work power, businesses, economic development activities concentrating around its capital Moscow. Such focus on one city hurts the development of the regions. Even though Moscow is the financial and economic centre of the country, housing conditions in the city are among the worst compared to the other areas (Churkina \& Zaverskiy, 2017).

Russia's economic development is closely related to the real estate market. Housing projects' development is of utmost importance for the country's social well being. However, further progress in the residential real estate market requires new sources of financing and help from government organisations (Tsertseil \& Kookueva, 2017).

Due to the current political climate and sanctions from the EU and USA as well as other economic factors, Russia suffers from a lack of investments and struggles to attract foreign capital to the country. It is argued that state support is needed for infrastructure projects as they would stimulate investments in commercial property. What is more, residential property constructions should be supported by subsidised mortgage lending plans and other means. So-called "investment drought" hurts the country's economic development, the demand is lowered by lack of capital expenditures, construction and industrial production growth are suppressed (Berezinskaya, 2017).

Also, high level of corruption in the governance of the country and business environment (Pavroz, 2017) hurts attracting investors.

\section{Use of MCDM methods for evaluation of real estate investments}

Multi-Criteria Decision-Making (MCDM) methods are often used to solve problems in social, medical sciences, economics, business and other (Nadaban, S. Dzitac, \& I. Dzitac, 2016). Nowadays dealing with complex issues in the 
marketplace requires an evaluation of multiple criteria. Each alternative in MCDM is described by a set of standards that can be qualitative and quantitative. It is identified that MCDM methods improve the quality of decisions through creating a more rational, efficient and explicit process of decision making (Zavadskas \& Turskis, 2010). MCDM methods are based on identifying the best solution from all feasible alternatives (Jahanshahloo, Hosseinzadeh Lofti, \& Izadikhah, 2006).

MCDM methods can be used for investment decisions in real estate. With the help of MCDM methods different EU and non-EU countries can be evaluated from multiple perspectives as a possible alternative for investments.

One of the most popular MCDM methods is the Technique for Order Performance by Similarity to Ideal Solution (TOPSIS).

TOPSIS is based on the idea that the selected alternative should have the shortest distance to the positive ideal solution and the farthest from the negative ideal solution (Wang \& Lee, 2009).

TOPSIS method consists of six steps:

1. Calculation of the normalised decision matrix;

2. Calculation of the weighted normalized decision matrix;

3. Determination of the positive ideal and negative ideal solutions;

4. Calculation of the separation measures by using the n-dimensional Euclidean distance;

5. Calculation of the relative closeness to the ideal solution;

6. Ranking the preference order (Jahanshahloo et al., 2006).

Another efficient MCDM method for selection of a country to invest in real estate in is ARAS (Additive Ratio Assesment). Zavadskas and Turskis (2010) proposed this method. In accordance to the ARAS method, it is stated that "a utility function value determining the complex relative efficiency of a feasible alternative is directly proportional to the relative effect of values and weights of the main criteria considered in a project" (Zavadskas, Turskis, \& Vilutiene, 2010).

ARAS method also consists of six steps:

1. Determination of optimal performance rating for each criterion;

2. Calculation of the normalised decision matrix;

3. Calculation of the weighted and normalised decision matrix;

4. Calculation of the overall performance index for each alternative;

5. Calculation of the degree of utility for each alternative;

6. Ranking alternatives and selecting the most efficient one (Stanujkic \& Jovanovic, 2012).

All in all, both TOPSIS and ARAS methods are applicable to evaluate countries for real estate investments.

\section{Conclusions}

Development of countries' economy is closely related to growth in real estate market. So investments in the real estate sector become of utmost importance to countries.

Various economic, political, social, environmental factors, laws and regulations, taxation system, corruption level etc. influence the attractiveness of a country as a potential investment in real estate destination.

Both EU (Lithuania, Romania, UK) and non-EU (Turkey, China, Russia) countries present various risks and opportunities for investments in real estate.

To evaluate which countries are most attractive for investment in real estate, MCDM methods could be used. The TOPSIS and ARAS methods applied to assess states as alternatives when selecting investment destination. Both ARAS and TOPSIS methods has a number of advantages and disadvantages. ARAS decision making technique is identified as one of the newest among all MCDM methods. Despite this fact, ARAS was put in application to solve different decision making problems (Stanujkic, 2015). A. Ozbek and E. Erol (2017) also acknowledge wide use of ARAS method and its effective application to solve problems like location choice for logistics centers, energy generation methods' choice, waste dump site selection and other. (Ozbek \& Erol, 2017) According to D. Stanujkic (2015) even though ARAS technique enables to solve a lot of decision making problems, application of interval-valued fuzzy numbers could extend use of ARAS even further.

Another multi criteria decision making method - TOPSIS - also has a number of advantages and disadvantages. M. Velasquez and P. T. Hester (2013) emphasize that this method is relatively simple and is easy to use. In addition, it is easy programmable. Another important advantage of TOPSIS technique is that number of steps in the process stays the same no matter how many attributes there are (Velasquez \& Hester, 2013). C. Hung and L. Chen (2009) also notes the simplicity of TOPSIS application as well as other advantages like high computational efficiency, rationally comprehensible concept and finally the possibility to evaluate relative performance of each alternative in uncomplicated mathematical form.

Wide application of TOPSIS in different fields (for example, engineering, logistics, business management etc.) has been influenced by its simplicity and same number of steps regardless of the size of the problem (Velasquez \& Hester, 2013). 
On the other hand, a number of disadvantages of TOPSIS model have been distinguished, for example correlations among criteria, unreliability of establishing the weights only by objective or subjective methods. (Xu, Y. Zhang, J. Zhang, \& Lv, 2015). M. Velasquez and P. T. Hester (2013) also indicate that TOPSIS application of Euclidean Distance does not take into consideration correlation of attributes. It is complicated to weight attributes and maintain judgment consistency, particularly with extra attributes (Velasquez \& Hester, 2013).

\section{Acknowledgements}

People who contributed to the work should be listed in the acknowledgments, along with their contributions. You must ensure that anyone named in the acknowledgments agrees to being named. Funding sources should be included in the form of a sentence as follows, with the funding agency written out in full, followed by the grant number in square brackets: This work was supported by the Medical Research Council [grant number 1111]. Multiple grant numbers should be separated by comma and space. Where the research was supported by more than one agency, the different agencies should be separated by semi-colon, with "and" before the final funder. Thus:

This work was supported by the Welcome Trust [grant numbers 1111, 2222]; the Natural Environment Research Council [grant number 3333]; and the Economic and Social Research Council [grant number 4444].

\section{References}

Anghel, I., \& Hristea, A. M. (2015). Some considerations regarding the international real estate market - present and future predictions. Procedia Economics and Finance, 32, 1442-1452. https://doi.org/10.1016/S2212-5671(15)01520-8

Bengtsson, E., Grothe, M., \& Lepers, E. (2018). Home, safe home: Cross-country monitoring framework for vulnerabilities in the residential real estate sector. Journal of Banking and Finance, 105268. https://doi.org/10.1016/j.jbankfin.2017.12.006

Berezinskaya, O. (2017). Investment drought in the Russian economy: Structural characteristics and turnaround perspectives. Russian Journal of Economics, 3, 71-82. https://doi.org/10.1016/j.ruje.2017.02.005

Allen \& Overy. (2016). Brexit - Implications for Real Estate. Allen \& Overy, June. Retrieved from http://www.allenovery.com/Brexit-Law/Documents/Business/Brexit\%20Implications\%20for\%20Real\%20Estate.pdf

Bunten, D., \& Kahn, M. E. (2017). Optimal real estate capital durability and localized climate change disaster risk. Journal of Housing Economics, 36, 1-7. https://doi.org/10.1016/j.jhe.2017.01.004

Cagli, E. C. (2018). Explosive behavior in the real estate market of Turkey. Borsa Istanbul Review. https://doi.org/10.1016/j.bir.2018.10.002

Canas, S. R. D., Ferreira, F. A. F., \& Meidute-Kavaliauskiene, I. (2015). Setting rents in residential real estate: A methodological proposal using multiple criteria decision analysis. International Journal of Strategic Property Management, 19(4), 368-380. https://doi.org/10.3846/1648715X.2015.1093562

Cetkovic, J., Lakic, S., Lazarevska, M., Zarkovic, M., Vujosevic, S., Cvijovic, J., \& Gogic, M. (2018). Assessment of the real estate market value in the European market by artificial neural networks application. Complexity, 2018, 1472957.

Chen, P., Wang, C., \& Liu, Y. (2015). Real estate prices and firm borrowings: Micro evidence from China. China Economic Review, 36, 296-308. https://doi.org/10.1155/2018/1472957

Churkina, N., \& Zaverskiy, S. (2017). Challenges of strong concentration in urbanization: the case of Moscow in Russia. Procedia Engineering, 198, 398-410. https://doi.org/10.1016/j.proeng.2017.07.095

Crowe, C., Dell'Ariccia, G., Igan, D., \& Rabanal, P. (2013). How to deal with real estate booms: Lessons from country experiences. Journal of Financial Stability, 9, 300-319. https://doi.org/10.1016/j.jfs.2013.05.003

Ding, D., Huang, X., Jin, T., \& Lam, W. R. (2017). The residential real estate market in China: Assesment and policy implications. Annals of Economics and Finance, 18-2, 411-442.

Fritzsche, C., \& Vandrei, L. (2019). The German real estate transfer tax: Evidence for single-family home transactions. Regional Science and Urban Economics, 74, 131-143. https://doi.org/10.1016/j.regsciurbeco.2018.08.005

Gaspareniene, L., Remeikiene, R., \& Skuka, A. (2016). Assessment of the impact of macroeconomic factors on housing price level: Lithuanian case. Intellectual Economics, 10, 122-127. https://doi.org/10.1016/j.intele.2017.03.005

Gokmen, A. (2014). A theoretical study on the concept of risk in enterprises, dynamics of risk in international business, investing in Turkey \& evaluation of macro risks abstract. Ege Academic Review, 14(2), 175-187. https://doi.org/10.21121/eab.2014218049

Golob, K., Bastic, M., \& Psunder, I. (2012). Analysis of impact factors on the real estate market: Case Slovenia. Inzinerine Ekonomika-Engineering Economics, 23(4), 357-367. https://doi.org/10.5755/j01.ee.23.4.2566

Grum, B., \& Govekar, D. K. (2016). Influence of macroeconomic factors on prices of real estate in various cultural environments: Case of Slovenia, Greece, France, Poland, Norway. Procedia Economics and Finance, 39, 597-604. https://doi.org/10.1016/S2212-5671(16)30304-5

Hung, C., \& Chen, L. (2009). A fuzzy topsis decision making model with entropy weight under intuitionistic fuzzy environment. In Proceedings of the International MultiConference of Engineers and Computer Scientists 2009 IMECS 2009, 18-20 March 2009, Hong Kong (vol. 1, pp. 13-16). 
Jahanshahloo, G. R., Hosseinzadeh Lofti, F., \& Izadikhah, M. (2006). An algorithm method to extend TOPSIS for decision-making problems with interval data. Applied Mathematics and Computation, 175, 1375-1384. https://doi.org/10.1016/j.amc.2005.08.048

Kelly, H. F. (2018). Under the radar: Real estate investment beyond the usual suspects. The Journal of the Center for Real Estate Studies, 8(1), 35-47.

Lieser, K., \& Groh, A. P. (2010). The attractiveness of 66 countries for institutional real estate investments: A composite index approach (Working Paper WP-868). University of Navarra. https://doi.org/10.2139/ssrn.1692165

Liu, C., \& Xiong, W. (2018). China's real estate market (Working paper). Retrieved from http://wxiong.mycpanel.princeton.edu/papers/HousingChapter.pdf https://doi.org/10.3386/w25297

ML, Z. (Zhang Minli), \& Wp, Y. (Yang Wenpo). (2012). Fuzzy comprehensive evaluation method applied in the real estate investment risks research. Physics Procedia, 24, 1815-1821. https://doi.org/10.1016/j.phpro.2012.02.267

Nadaban, S., Dzitac, S., \& Dzitac, I. (2016). Fuzzy TOPSIS: A general view. Procedia Computer Science, 91, 823-831. https://doi.org/10.1016/j.procs.2016.07.088

Olsson, N. O. E., Sorensen, A. O., \& Leikvan, G. (2015). On the need for iterative real estate project models - Applying agile methods in real estate developments. Procedia Economics and Finance, 21, 524-531. https://doi.org/10.1016/S2212-5671(15)00208-7

Ozbek, A., \& Erol, E. 2017. Ranking of factoring companies in accordance with ARAS and COPRAS methods. International Journal of Academic Research in Accounting, Finance and Management Sciences, 7(2), 105-116. https://doi.org/10.6007/IJARAFMS/v7-i2/2876

Panagiotidis, T., \& Printzis, P. (2015). On the macroeconomic determinants of the housing market in Greece: A VEMC approach (GeeSE Paper No. 88). Hellenic Observatory, European Institute.

Pavroz, A. (2017). Corruption-oriented model of governance in contemporary Russia. Communist and Post-Communist Studies, 50, 145-155. https://doi.org/10.1016/j.postcomstud.2017.05.005

Schiereck, D., Kiesel, F., \& Kolaric, S. (2016). Brexit: (Not) another lehman moment for banks? Finance Research Letters, 19, 291-297. https://doi.org/10.1016/j.frl.2016.09.003

Tsertseil, J. S., \& Kookueva, V. V. (2017). Problems of property market development in Russia in the modern context. Revista Espacios, 28(47).

Stanujkic, D., \& Jovanovic, R. (2012). Measuring a quality of faculty website using aras method. In Contemporary Issues in Business, Management and Education' 2012 (pp. 545-554). Retrieved from http://old.konferencijos.vgtu.lt/cbme.vgtu.lt/public_html/index.php/cbme/cbme_2012/paper/view/39/69

Stanujkic, D. (2015). Extension of the ARAS method for decision-making problems with interval-valued triangular fuzzy numbers. Informatica, 26(2), 335-355. https://doi.org/10.15388/Informatica.2015.51

Surd, V., Kassai, I., \& Giurgiu, L. (2011). Romania disparities in regional development. Procedia Social and Behavioral Sciences, 19, 21-30. https://doi.org/10.1016/j.sbspro.2011.05.102

Squires, G., \& Heurkens, E. (2016). Methods and models for international comparative approaches to real estate development. Land Use Policy, 50, 573-581. https://doi.org/10.1016/j.landusepol.2015.10.005

Tem, N. S. D., \& Komsuoglu Yilmaz, N. (2018). Determinants of residential real estate prices in Turkey. European Journal of Business and Social Sciences, 6(10), 41-54.

Tse, C. B., Rodgers, T., \& Niklewski, J. (2013). The 2007 financial crisis and the UK residential housing market: Did the relationship between interest rates and house prices change? Economic Modelling, 37, 518-530. https://doi.org/10.1016/j.econmod.2013.08.013

Tupenaite, L., Kanapeckiene, L., \& Naimaviciene, J. (2017). Determinants of housing market fluctuations: Case study of Lithuania. Procedia Engineering, 172, 1169-1175. https://doi.org/10.1016/j.proeng.2017.02.136

Velasquez, M., \& Hester, P. T. (2013). An analysis of multi-criteria decision making methods. International Journal of Operations Research, 10( 2), 56-66.

Wang, T., \& Lee, H. (2009). Developing a fuzzy TOPSIS approach based on subjective weights and objective weights. Expert Systems with Applications, 36, 8980-8985. https://doi.org/10.1016/j.eswa.2008.11.035

Wu, J., Gyourko, J., \& Deng, Y. (2015). Real estate collateral value and investment: The case of China. Journal of Urban Economics, 86, 43-53. https://doi.org/10.1016/j.jue.2014.12.006

Wu, W., \& Kou, G. (2016). A group consensus model for evaluating real estate investment alternatives. Financial Innovation, 2(8). https://doi.org/10.1186/s40854-016-0027-8

Xu, Q., Zhang, Y., Zhang, J., \& Lv, X. (2015). Improved TOPSIS model and its application in the evaluation of NCAA basketball coaches. Modern Applied Science, 9(2), 261-268. https://doi.org/10.5539/mas.v9n2p259

Zavadskas, E. K., \& Turskis, Z. (2010). A new Additive Ratio Assessment (ARAS) method in multicriteria decision-making. Technological and Economic Development of Economy, 16(2), 159-172. https://doi.org/10.3846/tede.2010.10

Zavadskas, E. K., Turskis, Z., \& Vilutiene, T. (2010). Multiple criteria analysis of foundation instalment alternatives by applying Addictive Ratio Assessment (ARAS). Archives of Civil and Mechanical Engineering, 10(3), 123-141. https://doi.org/10.1016/S1644-9665(12)60141-1

Zrobek, S., Trojanek, M., Zrobek-Sokolnik, A., \& Trojanek, R. (2015). The influence of environmental factors on property buyers' choice of residential location in Poland. Journal of International Studies, 8(3), 164-174 